Josefa Fernández* and M. J. Renedo

\title{
Sulfation and Carbonation Competition in the Treatment of Flue Gas from a Coal-Based Power Plant by Calcium Hydroxide
}

\begin{abstract}
In this work, a gas containing $\mathrm{CO}_{2}$ and $\mathrm{SO}_{2}$ at the usual concentrations on the coal combustion flue gas reacted with calcium hydroxide to evaluate and quantify the influence of $\mathrm{SO}_{2}$ on the $\mathrm{CO}_{2}$ capture and vice versa. This influence was quantified with a continuous gas analyzer and by thermogravimetry (TG). Results show that the $\mathrm{CO}_{2}$ retained increases in general as its concentration does and decreases as the $\mathrm{SO}_{2}$ concentration increases. A similar behavior was found for the $\mathrm{SO}_{2}$ retention at different $\mathrm{CO}_{2}$ concentrations being more relevant the influence of the presence of $\mathrm{SO}_{2}$ on the $\mathrm{CO}_{2}$ capture than the opposite one. Results suggest that for a high $\mathrm{CO}_{2}$ capture, $\mathrm{SO}_{2}$ should be eliminated previously. With respect to the reaction process it was found that the desulfurization product clearly identified was $\mathrm{CaSO}_{3} \cdot 1 / 2 \mathrm{H}_{2} \mathrm{O}$; in the reaction between $\mathrm{Ca}(\mathrm{OH})_{2}$ and $\mathrm{CO}_{2}, \mathrm{CaCO}_{3}$ is mainly obtained, the complex $\mathrm{CaO} \cdot \mathrm{CO}_{2}$ being another possible product synthesized in low amount. Gas analyzer shows that $\mathrm{SO}_{2}$ and $\mathrm{CO}_{2}$ react simultaneously and that a part of the $\mathrm{CaCO}_{3}$ reacts with the $\mathrm{SO}_{2}$ and releases $\mathrm{CO}_{2}$. Sulfation values calculated by $\mathrm{TG}$ and from the gas analyzer are very similar but the amount of $\mathrm{CO}_{2}$ captured is not possible to know clearly by TG due to the synthesis and decomposition of $\mathrm{CaCO}_{3}$ during the process. The study of the evolution of the sorbent porosity in the process reveals that the presence of both acid gases produces a lower blockage of the pores than when only one gas is present probably due to the generation of new pores in the reaction of $\mathrm{CaCO}_{3}$ and $\mathrm{SO}_{2}$.
\end{abstract}

Keywords: $\mathrm{CO}_{2}$ and $\mathrm{SO}_{2}$ capture, low temperature, flue gas, calcium hydroxide

DOI 10.1515/ijcre-2014-0182

\footnotetext{
*Corresponding author: Josefa Fernández, Chemistry and Process and Resources Engineering, Universidad de Cantabria, Avda. Los Castros s/n, 39005 Santander, Spain, E-mail:

josefa.fernandez@unican.es

M. J. Renedo, Chemistry and Process and Resources Engineering, Universidad de Cantabria, Avda. Los Castros s/n, 39005 Santander. Spain, E-mail: josefina.renedo@unican.es
}

\section{Introduction}

Coal combustion is one of the energy sources for electricity generation. Coal produced about $18 \%$ of Spanish electricity and recently, as Spain depends on coal industry for employment, the government, according to the European Community, approved to maintain subsidies for domestic coal used to generate energy up to 2014 [1]. The flue gas generated from coal combustion power plant contains $\mathrm{CO}_{2}$ (about 12\%) and $\mathrm{SO}_{2}$ at concentrations depending on the coal sulfur content, as well as $\mathrm{NO}_{x}$, $\mathrm{H}_{2} \mathrm{O}, \mathrm{O}_{2}$ and $\mathrm{N}_{2}$.

There are three main approaches to capture the $\mathrm{CO}_{2}$ generated from a primary fossil fuel or biomass, classified as post-combustion (capture from the flue gas), precombustion separations (capture in the gasification process, before the combustion step) and oxy-fuel firing, use of oxygen instead of air as comburent gas [2, 3, 4]. Developed post-combustion technology consists in the flue gas absorption in an aqueous solution with amines, mainly in the form of gas-liquid absorption columns. This technology is commonly used in various industries faced with the task of removing $\mathrm{CO}_{2}$ from gas mixtures containing a wide range of species in different concentrations [5, 6]. Adsorption at low temperatures (up to $423 \mathrm{~K}$ ) is considered one potential alternative with the added advantage that solids are easy to handle [7]. Carter, L.D [8] proposed the combined capture and storage of $\mathrm{CO}_{2}$ and $\mathrm{SO}_{2}$ or $\mathrm{H}_{2} \mathrm{~S}$ for conventional power plants to reduce cost in power production. The relevance of $\mathrm{CaO}, \mathrm{Ca}(\mathrm{OH})_{2}$ or calcium-based sorbents on the removal of acid gases, like $\mathrm{SO}_{2}, \mathrm{NO}_{x}, \mathrm{HCl}$ or $\mathrm{CO}_{2}$, justifies the great number of works focused on the preparation of efficient calciumbased sorbents. Arias et al. [9] studied the sulfation behavior of cycled $\mathrm{CaO}$ particles in Ca-looping $\mathrm{CO}_{2}$ capture system. Sun et al. [10] and Manovic and Anthony [11] found that $\mathrm{SO}_{2}$ impedes the cyclic $\mathrm{CO}_{2}$ capture by limestone or calcium aluminate pellets, because of the blockage by sulfation products, suggesting that desulfurization of flue gas before $\mathrm{CO}_{2}$ capture is essential for $\mathrm{CO}_{2}$ cyclic capture at high temperature. Several works have studied the process of simultaneous $\mathrm{CO}_{2}$ and $\mathrm{SO}_{2}$ retention by 
$\mathrm{CaO}$ or $\mathrm{Ca}(\mathrm{OH})_{2}$ at medium or low temperature and at the usual $\mathrm{CO}_{2}$ and $\mathrm{SO}_{2}$ concentration in the flue gas of a coalbased power station. Kramer et al. [12] stated the main reactions implied in the desulfurization process with $\mathrm{Ca}(\mathrm{OH})_{2}$ when $\mathrm{CO}_{2}$ was present. Guang et al. [13], working with $\mathrm{Ca}(\mathrm{OH})_{2}$, injected in the flue gas, at temperatures about $500^{\circ} \mathrm{C}, \mathrm{SO}_{2}$ concentrations of 3,000 or $1,500 \mathrm{ppm}$ and $\mathrm{CO}_{2}$ concentrations of $14 \%$ found that the carbonation of the sorbent hinders the $\mathrm{SO}_{2}$ capture even though slight alterations in $\mathrm{CO}_{2}$ concentrations did not have significant effects on the $\mathrm{SO}_{2}$ removal. Ho et al. [14] proved that when $\mathrm{O}_{2}, \mathrm{CO}_{2}$ and $\mathrm{SO}_{2}$ were present in the flue gas, the sulfation and carbonation reactions took place simultaneously and the carbonate formed further reacted with $\mathrm{SO}_{2}$ to form sulfite. Liu et al. [15], working at the conditions similar to those in the bag filters of dry or semi-dry flue gas desulfurization (FGD) systems, found when $\mathrm{CO}_{2}$ and $\mathrm{SO}_{2}$ are present that the final carbonate amount was lower than when only $\mathrm{CO}_{2}$ is present because the $\mathrm{CaCO}_{3}$ reacts with $\mathrm{SO}_{2}$. For a constant $\mathrm{CO}_{2}$ concentration of $12.6 \%$, the $\mathrm{SO}_{2}$ capture after $1 \mathrm{~h}$ of reaction was nearly independent on the $\mathrm{SO}_{2}$ concentration from 1,000 to $50 \mathrm{ppm}$ of $\mathrm{SO}_{2}$ and this capture was insensitive to the presence of $\mathrm{CO}_{2}$.

In a previous work [16], experiments of chemisorption of $\mathrm{CO}_{2}$ at $50^{\circ} \mathrm{C}$ were performed with a dry flue gas $(10 \%$ $\mathrm{CO}_{2}$ in $\mathrm{He}$ ), commercial $\mathrm{Ca}(\mathrm{OH})_{2}$ and with this hydroxide supported on mesoporous materials to investigate the possibility of a cyclic $\mathrm{CO}_{2}$ capture at low temperature. In that work, it was found that $\mathrm{CO}_{2}$ was retained as a $\mathrm{CaO} \cdot \mathrm{CO}_{2}$ complex and also as $\mathrm{CaCO}_{3}$ in higher amounts. Even when the amount of $\mathrm{CO}_{2}$ retained as $\mathrm{CaO} \cdot \mathrm{CO}_{2}$ was low, the sorbents could be regenerated at $550^{\circ} \mathrm{C}$ and used cyclically without appreciable loss in activity.

In the present work, the influence of the presence of $\mathrm{SO}_{2}$ and $\mathrm{CO}_{2}$, at the usual concentrations in a coal combustion flue gas, on the co-capture of both gases by calcium hydroxide at low temperature is studied. The objectives were to know the reaction process and the products synthesized to explain the modification of the sorbent porosity and the influence of the presence of one gas on the capture of the other one, quantifying with two different techniques, this influence. All of this information will be used to predict the influence of the presence of $\mathrm{SO}_{2}$ on the cyclic $\mathrm{CO}_{2}$ capture by $\mathrm{Ca}(\mathrm{OH})_{2}$ at low temperature.

\section{Experimental section}

A commercial $\mathrm{Ca}(\mathrm{OH})_{2}$, supplied by Calcinor, was used as sorbent.

A Camsizer XT from Retsch with the dry dispersion module was used to obtain the particle size distribution of the sorbent. The isotherm of the commercial calcium hydroxide before and after the reaction was obtained by using a Micromeritics ASAP-2010 apparatus by $\mathrm{N}_{2}$ adsorption. The specific surface area was calculated using the BET (Brunauer, Emmett, Teller) method and the pore size distribution from the desorption branch of the isotherm following the BJH (Barreto, Joyner \& Halenda) procedure. A Setaram thermal analyzer model SETSYS-1700 was used for the thermogravimetric (TG) curve determination.

\subsection{Reaction of the sorbent with $\mathrm{CO}_{2}$ and $\mathrm{SO}_{2}$}

In the laboratory experimental setup, shown in Figure 1, a flue gas containing $\mathrm{CO}_{2}$ and $\mathrm{SO}_{2}$, at the usual concentrations in the exhausted gas of a coal combustion power station, is conducted through commercial $\mathrm{Ca}(\mathrm{OH})_{2}$, used as sorbent. The concentration of $\mathrm{SO}_{2}$ and $\mathrm{CO}_{2}$ after the reaction was continuously monitored in an Emerson MLT1 NGA 2000 gas analyzer and data were compiled with a personal computer equipped with NGA win control software. The breakthrough curves of both gases were plotted

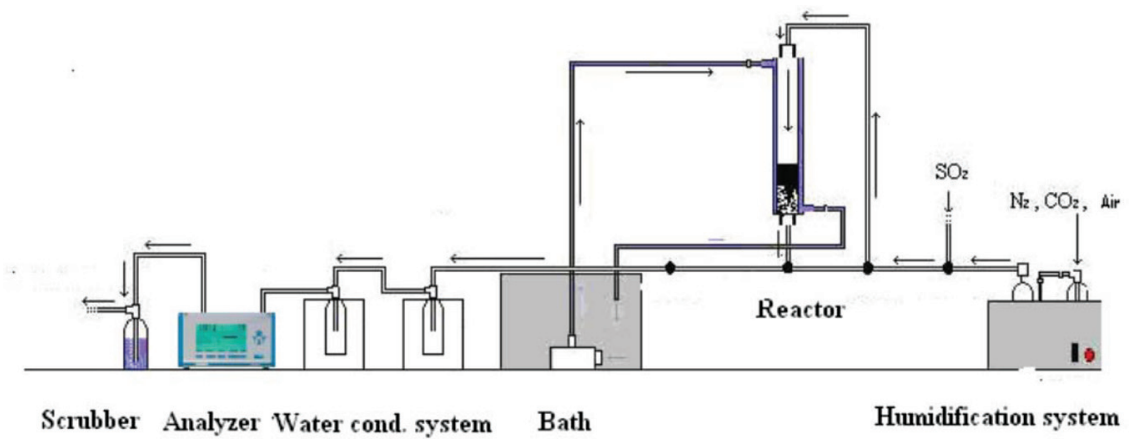

Figure 1 Experimental setup of the reaction process 
with the analyzer data and the calcium utilization of the sorbent in the reaction with $\mathrm{CO}_{2}$ and $\mathrm{SO}_{2}$ and the total calcium utilization were obtained from the area above the curve. One gram of the sorbent, commercial calcium hydroxide, dispersed in $30 \mathrm{~g}$ of inert silica sand was placed in a $3.6 \mathrm{~cm}$ diameter glass-made jacketed fixed bed reactor at $55 \%$ of relative humidity and at temperature of $58^{\circ} \mathrm{C}$. The composition of the gas stream was $12 \%$ or $6 \%$ or $0 \% \mathrm{CO}_{2} ; 9.5 \%$ synthetic air; $5,000,2,500,1,000$ or $0 \mathrm{ppm} \mathrm{SO} \mathrm{S}_{2}$ and balanced $\mathrm{N}_{2}$, being $1,000 \mathrm{ml} / \mathrm{min}$ the flue gas rate.

Table 1 shows the concentrations of the acid gases essayed. Three runs were performed for each condition. When the reaction time was over, $1 \mathrm{~h}$ approximately, (controlled by the breakthrough curves), the reacted sorbent was sieved to separate it from the sand. Some of the reacted sorbents were submitted to TG analysis.

\subsubsection{Determination of the calcium utilization or calcium conversion in the reaction with $\mathrm{CO}_{2}$ or $\mathrm{SO}_{2}$ and of the total calcium utilization}

The calcium utilization or the calcium conversion in the reaction of $\mathrm{Ca}(\mathrm{OH})_{2}$ with $\mathrm{CO}_{2}$ or $\mathrm{SO}_{2}$ in percentage is defined as:

$$
\frac{\text { moles of } \mathrm{CO}_{2} \text { captured / grams of sorbent }}{\text { moles of calcium / grams of sorbent }} \times 100 \text { or }
$$

$$
\frac{\text { moles of } \mathrm{SO}_{2} \text { captured / grams of sorbent }}{\text { moles of calcium / grams of sorbent }} \times 100
$$

The sum of these two terms will be the total calcium utilization. The moles of $\mathrm{CO}_{2}$ and $\mathrm{SO}_{2}$ captured, at any time and after $1 \mathrm{~h}$ of reaction, were calculated from the area above the breakthrough curves. For sorbents submitted to TG analysis, the amounts of $\mathrm{CO}_{2}$ or $\mathrm{SO}_{2}$ were also obtained from TG data. The moles of calcium in the sorbent were calculated considering the commercial calcium hydroxide composition. To calculate the calcium utilization in the reaction with $\mathrm{CO}_{2}$ by $\mathrm{TG}$ it must be considered that the $\mathrm{CaCO}_{3}$ present in the reacted sorbent is mainly due to the $\mathrm{CaCO}_{3}$ present in the commercial $\mathrm{Ca}(\mathrm{OH})_{2}$, the $\mathrm{CaCO}_{3}$ synthesized with the $\mathrm{CO}_{2}$ captured and the $\mathrm{CaCO}_{3}$ disappeared by reaction with $\mathrm{SO}_{2}$.

\section{Results and discussion}

Particle size distribution of the commercial $\mathrm{Ca}(\mathrm{OH})_{2}$ obtained with the Camsizer shows that $100 \%$ of the sample is lower than $200 \mu \mathrm{m}$, being $90 \%$ lower than $80 \mu \mathrm{m}$ and $10 \%$ lower than $10 \mu \mathrm{m}$. The purity of the commercial $\mathrm{Ca}(\mathrm{OH})_{2}$ determined by TG analysis using $\mathrm{N}_{2}$ as purge gas was $82.7 \%$ being $9 \%$ the $\mathrm{CaCO}_{3}$ content. The specific surface area of the commercial $\mathrm{Ca}(\mathrm{OH})_{2}$ calculated following the BET method was $13 \mathrm{~m}^{2} / \mathrm{g}$.

\subsection{Reaction process and products identification}

Breakthrough curves of $\mathrm{CO}_{2}$ and $\mathrm{SO}_{2}$ were discussed in a previous work [17], showing that both gases react simultaneously with the calcium hydroxide according to $\mathrm{Ho}$ et al. [14]. Furthermore, the $\mathrm{CO}_{2}$ breakthrough curve shows at about $600 \mathrm{~s}$, a gas concentration higher than the initial one due to the reaction of $\mathrm{SO}_{2}$ with $\mathrm{CaCO}_{3}$ that releases $\mathrm{CO}_{2}$. From the area above the breakthrough curves and applying eq. (1), conversion values at any time and after $1 \mathrm{~h}$ of reaction are calculated. Results are shown in Table 2.

Table 1 Concentrations of $\mathrm{SO}_{2}$ and $\mathrm{CO}_{2}$ at different runs

\begin{tabular}{lrrrrrrrrr}
\hline $\mathrm{SO}_{2}$ conc. (ppm) & 0 & 1,000 & 2,500 & 5,000 & 1,000 & 2,500 & 5,000 & 1,000 & 2,500 \\
$\mathrm{CO}_{2}$ conc. $(\%)$ & 12 & 12 & 12 & 12 & 6 & 6 & 6 & 0 & 0 \\
\hline
\end{tabular}

\begin{tabular}{|c|c|c|c|c|c|c|c|c|c|}
\hline $\mathrm{CO}_{2}$ conc. (\%) & 12 & 12 & 12 & 12 & 6 & 6 & 6 & 0 & 0 \\
\hline $\mathrm{SO}_{2}$ conc. (ppm) & 5,000 & 2,500 & 1,000 & 0 & 5,000 & 2,500 & 1,000 & 5,000 & 2,500 \\
\hline $\mathrm{Ca}(\mathrm{OH})_{2}$ conv. to $\mathrm{CaSO}_{3}(\%)$ & $14.8 \pm 0.5$ & $11 \pm 1$ & $10.7 \pm 0.6$ & & $15.1 \pm 0.9$ & $13 \pm 2$ & $10 \pm 1$ & $20 \pm 2$ & $17.6 \pm 0.9$ \\
\hline $\mathrm{Ca}(\mathrm{OH})_{2}$ conv. to $\mathrm{CaCO}_{3}(\%)$ & $14 \pm 1$ & $16 \pm 1$ & $20 \pm 2$ & $27.0 \pm 0.6$ & $11 \pm 1$ & $10.4 \pm 0.8$ & $10.2 \pm 0.7$ & & \\
\hline Total $\mathrm{Ca}(\mathrm{OH})_{2}$ conversion (\%) & $29 \pm 2$ & $27 \pm 2$ & $31 \pm 3$ & & $26 \pm 2$ & $23 \pm 3$ & $20 \pm 2$ & & \\
\hline
\end{tabular}

Table 2 Mean values (of three runs) \pm standard deviation of calcium conversion in the reaction with $\mathrm{SO}_{2}$ or $/ \mathrm{and}^{\mathrm{C}} \mathrm{O}_{2}$ for different experimental conditions 
In that previous work, the calcium conversion in the reaction with $\mathrm{SO}_{2}$ or $\mathrm{CO}_{2}$ versus time showed different shapes mainly at the beginning of the process, principally due to the great differences in $\mathrm{SO}_{2}$ and $\mathrm{CO}_{2}$ concentration in the gas mixture (Table 1) and in consequence a great difference in their reaction rates. The calcium conversions with time in the reaction with $\mathrm{CO}_{2}$ showed a first step in which the reaction of $\mathrm{Ca}(\mathrm{OH})_{2}$ with $\mathrm{CO}_{2}$ was very fast, in a chemically controlled process; this step was followed by a period diffusional controlled with a slow $\mathrm{CO}_{2}$ capture or even with no appreciable capture. The calcium conversions with time in reaction with $\mathrm{SO}_{2}$ showed that the $\mathrm{SO}_{2}$ capture increased at any time with its concentration for a $\mathrm{CO}_{2}$ constant concentration, being the highest $\mathrm{SO}_{2}$ capture when $\mathrm{CO}_{2}$ was not present.

A great difference in the $\mathrm{CO}_{2}$ capture depending on the presence of $\mathrm{SO}_{2}$ in the flue gas was also found ( $27 \%$ without $\mathrm{SO}_{2}$ and $14 \%$ with 5,000 ppm of $\mathrm{SO}_{2}$ and $12 \%$ of $\mathrm{CO}_{2}$, after 1 $\mathrm{h}$ of reaction, as Table 2 shows). Liu et al. [15], working at similar temperature, relative humidity and $\mathrm{CO}_{2}$ concentration, found a $\mathrm{CO}_{2}$ capture, after $1 \mathrm{~h}$ of reaction, very similar to that found in this work, when $\mathrm{SO}_{2}$ was not present.

In all runs performed with both gases, except in experiments with $12 \%, \mathrm{CO}_{2}$ and $1,000 \mathrm{ppm} \mathrm{SO}_{2}$, there is a time period, at about $600 \mathrm{~s}$, with values of $\mathrm{CO}_{2}$ concentrations higher than the initial one, revealing a net $\mathrm{CO}_{2}$ production. The $\mathrm{CaCO}_{3}$ present in the sorbent or produced in the reaction of $\mathrm{Ca}(\mathrm{OH})_{2}$ and $\mathrm{CO}_{2}$ reacts with $\mathrm{SO}_{2}$, a stronger acid than $\mathrm{CO}_{2}$, and releases $\mathrm{CO}_{2}$. Although this reaction occurs all the time, only when the amount of $\mathrm{CO}_{2}$ captured is lower than the amount of this gas released, a net $\mathrm{CO}_{2}$ emission is detected. In the experiment performed without $\mathrm{CO}_{2}$ and 5,000 ppm of $\mathrm{SO}_{2}, \mathrm{CO}_{2}$ emissions were also detected, meaning that the $\mathrm{CaCO}_{3}$ present in the commercial $\mathrm{Ca}(\mathrm{OH})_{2}$ also reacts with $\mathrm{SO}_{2}$. These results obtained from analyzer data were confirmed by mass spectrometry (MS) analysis [17].

TG, differential scanning calorimetry (DSC) and MS results of the sorbent before and after the reaction allowed us in a previous work [17] to explain and discuss the analyzer data, the reactions that occur in the process and the conversion results obtained. $\mathrm{CaSO}_{3} \cdot 1 / 2 \mathrm{H}_{2} \mathrm{O}$ was the unique desulfurization product clearly identified. $\mathrm{CaSO}_{4}$ was not identified by TG-MS as MS peaks of $\mathrm{SO}_{3}$ were not found, probably due to the decomposition of the calcium sulfate at elevated temperatures to form $\mathrm{CaO}, \mathrm{SO}_{2}$ and $\mathrm{O}_{2}$ according to bibliography [18]. $\mathrm{CaCO}_{3}$ is the main product of $\mathrm{CO}_{2}$ capture and $\mathrm{CaO} \cdot \mathrm{CO}_{2}$, another product. DSC and MS data allowed distinguishing the calcination of the $\mathrm{CaCO}_{3}$ formed from the $\mathrm{CO}_{2}$ capture than that present in the initial sorbent.
Table $3 \mathrm{Ca}(\mathrm{OH})_{2}$ conversion values obtained from gas analyzer data and from TG data

\begin{tabular}{lrr}
\hline $\begin{array}{l}\mathrm{CO}_{2}(\%) / \mathrm{SO}_{2} \\
(\mathrm{ppm})\end{array}$ & $\begin{array}{r}\mathrm{Ca}(\mathrm{OH})_{2} \text { conversion to } \\
\mathrm{CaCO}_{3}(\%) \text { gas analyzer/ } \\
\text { concentrations }\end{array}$ & $\begin{array}{r}\mathrm{Ca}(\mathrm{OH})_{2} \text { conversion to } \\
\mathrm{CaSO}_{3}(\%) \text { gas } \\
\text { analyzer/TG }\end{array}$ \\
\hline $12 / 5,000$ & $14.3 / 24.0$ & $14.7 / 14.2$ \\
& $13.6 / 13.0$ & $15.6 / 15.2$ \\
$12 / 2,500$ & $14.6 / 4.4$ & $10.1 / 12.4$ \\
$12 / 1,000$ & $20.0 / 13.1$ & $9.5 / 9.4$ \\
$12 / 0$ & $27 / 10.3$ & \\
$0 / 5,000$ & & $18.8 / 19.0$ \\
\hline
\end{tabular}

According to the objectives of the work, Table 3 shows conversion values obtained after $1 \mathrm{~h}$ of reaction with two different techniques, from gas analyzer and from TG data of the reacted sorbent. Results show that the calcium conversion values in the reaction with $\mathrm{SO}_{2}$ are very similar independently of the experimental procedure used to calculate it, but there is no concordance in the results of calcium conversion in the reaction with $\mathrm{CO}_{2}$. In the calculation of conversion to $\mathrm{CaCO}_{3}$ from gas analyzer data, the moles of $\mathrm{CO}_{2}$ are the net amount of this gas captured. Conversion values from TG data are calculated from the final $\mathrm{CaCO}_{3}$ remaining in the sorbent after $1 \mathrm{~h}$ of reaction that, as has been explained, depends on three different processes: the $\mathrm{CaCO}_{3}$ present in the commercial $\mathrm{Ca}(\mathrm{OH})_{2}$, the $\mathrm{CaCO}_{3}$ synthesized with the $\mathrm{CO}_{2}$ captured and the $\mathrm{CaCO}_{3}$ disappeared by reaction with $\mathrm{SO}_{2}$. Because of that, TG technique is not a good tool to quantify the real amount of $\mathrm{CO}_{2}$ captured and it is better to use the gas analyzer data.

Table 2 shows the mean values (obtained from three runs for each condition) of calcium conversion in the reaction with $\mathrm{SO}_{2}$ or $\mathrm{CO}_{2}$ obtained from gas analyzer data after $1 \mathrm{~h}$ of reaction and values of total $\mathrm{Ca}(\mathrm{OH})_{2}$ conversion. As values show, the capture of $\mathrm{SO}_{2}$ increases with $\mathrm{SO}_{2}$ concentration for a constant $\mathrm{CO}_{2}$ concentration and also increases as $\mathrm{CO}_{2}$ concentration decreases though this influence is nearly inappreciable at the conditions essayed. The $\mathrm{CO}_{2}$ capture increases with $\mathrm{CO}_{2}$ concentration for a constant $\mathrm{SO}_{2}$ concentration and decreases as $\mathrm{SO}_{2}$ concentration increases for a constant $12 \%$ concentration of $\mathrm{CO}_{2}$. For a $\mathrm{CO}_{2}$ concentration of $6 \%$ there is almost no variation on $\mathrm{CO}_{2}$ capture at different $\mathrm{SO}_{2}$ concentrations. Results obtained at the usual $\mathrm{SO}_{2}$ and $\mathrm{CO}_{2}$ concentrations in the flue gas of $2,500 \mathrm{ppm}$ and $12 \%$ confirm that both acid gases compete to react with the base. But results of Table 2 and previous work also show that at these usual concentrations, the presence of $\mathrm{SO}_{2}$ has a higher influence on the $\mathrm{CO}_{2}$ capture $\left(\mathrm{Ca}(\mathrm{OH})_{2}\right.$ 
conversion values to $\mathrm{CaCO}_{3}$ varied from $15.6 \%$ to $27.0 \%$ as the $\mathrm{SO}_{2}$ concentration goes from 2,500 to $0 \mathrm{ppm}$ ) than the presence of $\mathrm{CO}_{2}$ on the $\mathrm{SO}_{2}$ capture (conversion to $\mathrm{CaSO}_{3}$ varied from $11.9 \%$ to $17.6 \%$ as the $\mathrm{CO}_{2}$ concentrations diminishes from $12 \%$ to $0 \%$ ). Guan et al. [13] found that slight alterations in $\mathrm{CO}_{2}$ concentrations did not have significant effects on the $\mathrm{SO}_{2}$ removal and Liu et al. [15] also found little variation on the $\mathrm{SO}_{2}$ capture when $\mathrm{CO}_{2}$ at $12.6 \%$ of concentration was or was not present. Although the rapid reaction of $\mathrm{CO}_{2}$ with $\mathrm{Ca}(\mathrm{OH})_{2}$ at the beginning of the process to form $\mathrm{CaCO}_{3}$ blocks the pore holes and hinders the diffusion of $\mathrm{SO}_{2}$, the desulfurant properties of the salt and the lower acidity of $\mathrm{CO}_{2}$ explain that the real influence of $\mathrm{CO}_{2}$ on the $\mathrm{SO}_{2}$ capture is less relevant than vice versa. The same considerations can be used to explain that despite the great difference in the concentrations of both gases, the moles of $\mathrm{SO}_{2}$ and $\mathrm{CO}_{2}$ captured are very similar.

When both gases are present, total conversion of calcium hydroxide is the highest, the base is more efficiently used; but if the aim of the process is to retain $\mathrm{CO}_{2}$, considering the great influence of the $\mathrm{SO}_{2}$ on its capture, it would be more convenient, as it has been proposed, to desulfurize previously the gas [15]. If the co-capture is the option, conversion results obtained quantify the $\mathrm{CO}_{2}$ capture reduction, related to the presence of $\mathrm{SO}_{2}$ at the conditions essayed in this work.

In a previous work [19], the variation of the specific surface area of calcium hydroxide before and after its reaction with $\mathrm{CO}_{2}$ and/or $\mathrm{SO}_{2}$ at the concentration of $12 \%$ and 5,000 ppm, respectively, was studied. Results indicate that after the reaction with both gases the specific surface area of the sorbent is slightly higher than after the reaction with each gas alone. Figure 2 shows the pore size distribution of $\mathrm{Ca}(\mathrm{OH})_{2}$ before and after the reaction at the same conditions used in that previous work. This figure shows a high pore blockage after the reaction due to the solid products, mainly $\mathrm{CaCO}_{3}$ and $\mathrm{CaSO}_{3} \cdot 1 / 2 \mathrm{H}_{2} \mathrm{O}$. Within the reacted sorbents, the highest remaining porosity corresponds to the sorbent after the reaction with both gases. This result can be explained, at least in part, considering that when both gases are present, the $\mathrm{CaCO}_{3}$ reacts with $\mathrm{SO}_{2}$ releasing $\mathrm{CO}_{2}$ and generating new pores. That means that when calcium hydroxide is used to retain $\mathrm{CO}_{2}$ in the presence of $\mathrm{SO}_{2}$, at low temperature, the reversible adsorption of $\mathrm{CO}_{2}$ as $\mathrm{CaO} \cdot \mathrm{CO}_{2}$, found in the previous work [16] could be higher than without $\mathrm{SO}_{2}$, due to the higher porosity available.

\section{Conclusions}

The study of the reaction of $\mathrm{CO}_{2}$ and $\mathrm{SO}_{2}$ with commercial calcium hydroxide at low temperature in a continuous gas analyzer proves and quantifies the simultaneous reaction of the sorbent with both gases and the $\mathrm{CO}_{2}$ release in the reaction of $\mathrm{CaCO}_{3}$ with $\mathrm{SO}_{2}$.

According to previous TG-DSC-MS results, the main reaction product of calcium hydroxide and $\mathrm{SO}_{2}$ at this low temperature is $\mathrm{CaSO}_{3} \cdot 1 / 2 \mathrm{H}_{2} \mathrm{O}$. The main product of the reaction of $\mathrm{CO}_{2}$ and $\mathrm{Ca}(\mathrm{OH})_{2}$ is $\mathrm{CaCO}_{3}$. The detection by MS of little amounts of $\mathrm{CO}_{2}$ released within $425-525^{\circ} \mathrm{C}$ and the difference between the $\mathrm{Ca}(\mathrm{OH})_{2}$ reacted and the $\mathrm{CaCO}_{3}$ formed when $\mathrm{SO}_{2}$ is not present suggest the possible formation of a $\mathrm{CaO} \cdot \mathrm{CO}_{2}$ complex, postulated in a previous work.

Only data of the gas analyzer allow determining the $\mathrm{CO}_{2}$ captured, while the $\mathrm{SO}_{2}$ captured can also be determined from TG data. Results of calcium conversion show that both acid gases compete to react with the base but it

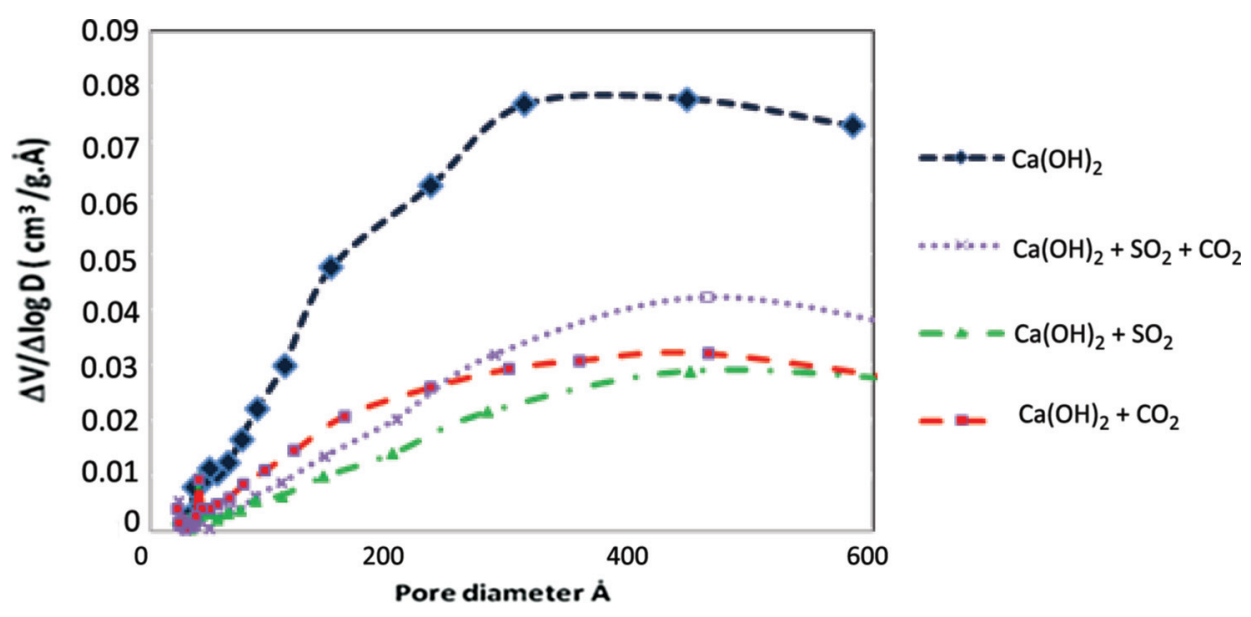

Figure 2 Pore size distribution of $\mathrm{Ca}(\mathrm{OH})_{2}$ before and after the reactions 
is higher than the influence of $\mathrm{SO}_{2}$ on the $\mathrm{CO}_{2}$ capture than the influence of $\mathrm{CO}_{2}$ on the $\mathrm{SO}_{2}$ retention. That result can be explained considering that $\mathrm{CO}_{2}$ is a weaker acid than $\mathrm{SO}_{2}$ and that $\mathrm{CaCO}_{3}$ acts as desulfurant.

Despite the higher $\mathrm{CO}_{2}$ concentrations with respect to $\mathrm{SO}_{2}$, in all the conditions tested $\left(12 \%\right.$ or $6 \% \mathrm{CO}_{2}$ versus maximum 5,000 ppm $\mathrm{SO}_{2}$ ), the strongest acidity of $\mathrm{SO}_{2}$ makes that the moles of the base that react with both gases are of similar order of magnitude. When both gases are present the base is more efficiently used (total calcium conversion is higher than the conversion with one gas).

According to these conclusions obtained working at low temperature, if the purpose of the process is mainly to retain $\mathrm{CO}_{2}$, it is convenient to desulfurize previously the flue gas. If the aim is to co-capture, this work shows the reduction on the retention of each gas when both gases are present. Nevertheless, as the porosity reduction after the reaction with both gases is lower than the reduction with one gas, it is predictable that the reversible adsorption of $\mathrm{CO}_{2}$ as $\mathrm{CaO} \cdot \mathrm{CO}_{2}$ could be higher than without $\mathrm{SO}_{2}$.

Acknowledgements: We are thankful to MICINN in Spain, National Plan for Scientific Research, Development and Innovation, for financial support under Project: MAT2010-18862 and to the University of Cantabria, Project Ref. 51.VP10.64005.

\section{References}

1. BOE Núm. 51, 27 de febrero de 2010 Sec. I. Pág. 19123. Real Decreto134/2010, de 12 de febrero.

2. Rojey A, Torp TA. Capture and geological storage of $\mathrm{CO}_{2}$ : an overview. Oil Gas Sci Technol 2005;60:445.

3. Stephens JC, van der Zwaan B. $\mathrm{CO}_{2}$ capture and storage (CCS): exploring the research, development, demonstration and deployment continuum, BCSIA discussion paper, Harvard University, 2005:1-20.

4. IPPC Special Report on carbon dioxide capture and storage. Intergovernmental panel on climate change. Cambridge University Press, 2005.

5. Minchener AJ, McMullan JT. Sustainable clean coal power generation within a European context - the view in 2006. Fuel 2007;86:2124.
6. Satyapal S, Filburn T, Trela J, Strange J. Performance and properties of a solid amine sorbent for carbon dioxide removal in space life support applications. Energy Fuels 2001;15:250.

7. Veawap A, Tontiwachwuthikul P, Chakma A. Corrosion behavior of carbon steel in the $\mathrm{CO}_{2}$ absorption process using aqueous amine solutions. Ind Eng Chem Res 1999;38:39.

8. Carter LD. United States carbon sequestration council. Capture and storage of $\mathrm{CO}_{2}$ with other air pollutants. IEA Clean Coal Centre, January 2010.

9. Arias B, Cordero JM, Alonso M, Abanades JC. Sulfation rates of cycled $\mathrm{CaO}$ particles in the carbonator of a Ca-looping cycle for postcombustion $\mathrm{CO}_{2}$ capture. AIChE J 2012;58:2262.

10. Sun P, Grace JR, Lim CJ, Anthony EJ. Removal of $\mathrm{CO}_{2}$ by calcium based sorbents in the presence of $\mathrm{SO}_{2}$. Energy Fuels 2007;21:163-70.

11. Manovic V, Anthony EJ. Competition of sulfation and carbonation reactions during looping cycles for $\mathrm{CO}_{2}$ capture by $\mathrm{CaO}$ based sorbents. J Phys Chem A 2010;114:3997-4002.

12. Kramer G, Brunner Ch, Khinast J, Staudinger G. Reaction of $\mathrm{Ca}(\mathrm{OH})_{2}$ with $\mathrm{SO}_{2}$ at low temperature. Ind Eng Chem Res 1997;36:1410-18.

13. Guang GL, Keener TC, Stein AW, Khang SJ. $\mathrm{CO}_{2}$ reaction with $\mathrm{Ca}(\mathrm{OH})_{2}$ during $\mathrm{SO}_{2}$ removal with convective pass sorbent injection and high temperature filtration. Environ Eng Policy 2000;2:47-56.

14. Ho C-S, Shih S-M, Lee C-D. Influence of $\mathrm{CO}_{2}$ and $\mathrm{O}_{2}$ on the reaction of $\mathrm{Ca}(\mathrm{OH})_{2}$ under spray-drying flue gas desulfurization conditions. Ind Eng Chem Res 1996;35:3915-19.

15. Liu C-F, Shih S-M, Tsai-Bang $\mathrm{H}$. Effect of $\mathrm{SO}_{2}$ on the reaction of calcium hydroxide with $\mathrm{CO}_{2}$ at low temperatures. Ind Eng Chem Res 2010;49:9052-7.

16. Fernández J, González F, Pesquera C, Blanco C, Renedo MJ. Study of $\mathrm{CO}_{2}$ /sorbent interaction in sorbents prepared with mesoporous support and calcium compounds. Ind Eng Chem Res 2010;49:2986-91.

17. Renedo MJ, Pesquera C, González F, Fernández J. Use of TG-DSC-MS and gas analyzer data to investigate the reaction of $\mathrm{CO}_{2}$ and $\mathrm{SO}_{2}$ by $\mathrm{Ca}(\mathrm{OH})_{2}$ at low temperature. CET 2013;35:739-44.

18. Swift WM, Panek AF, Smith GW, Vogel GJ, Jonke AA. Decomposition of calcium sulfate: a review of the literature Technical Report Number: ANL-76-122, Argone National Lab., IL, USA, 1976.

19. Renedo MJ, Pesquera C, González F, Ortiz B, Blanco C, Fernández J. Evolution of the sorbent structure in the simultaneous retention of $\mathrm{CO}_{2}$ and $\mathrm{SO}_{2}$ by $\mathrm{Ca}(\mathrm{OH})_{2}$. In: The 3rd International Congress of GPE, Kuala-Lumpur, (Malaysia), 2011: 229-20. 